Article

\title{
Our Cherished Moments of Involuntary Realism: Charles Harrison, Modernism, and Art Writing
}

\author{
Stephen Moonie
}

check for

updates

Citation: Moonie, Stephen. 2022. Our Cherished Moments of Involuntary

Realism: Charles Harrison,

Modernism, and Art Writing. Arts 11:

23. https://doi.org/10.3390/

arts11010023

Academic Editor: John Zarobell

Received: 30 November 2021

Accepted: 17 January 2022

Published: 21 January 2022

Publisher's Note: MDPI stays neutral with regard to jurisdictional claims in published maps and institutional affiliations.

Copyright: (C) 2022 by the author. Licensee MDPI, Basel, Switzerland. This article is an open access article distributed under the terms and conditions of the Creative Commons Attribution (CC BY) license (https:// creativecommons.org/licenses/by/ $4.0 /)$.
Department of Fine Art, School of Arts and Cultures, Newcastle University, Newcastle NE1 7RU, UK; stephen.moonie@newcastle.ac.uk

\begin{abstract}
In May 1969, Charles Harrison reviewed Morris Louis' exhibition at the Waddington Galleries in London. Months later, he helped to install the exhibition When Attitudes Become Form at the Institute of Contemporary Arts. Harrison also wrote the catalogue text, published in Studio International. Those two texts marked a significant point in Harrison's career. They were indicative of his disillusionment with modernist criticism, and of his burgeoning interest in the work of postminimal and conceptual art. In this respect, the two essays mark a transition from modernism to post-modernism in the space between a formalist analysis of the art object and a more dispersed field of artistic practice, where a changed relationship between art practice, criticism, and curating was taking place. However, in the 2000s, Harrison came to reflect upon this cardinal moment. Harrison referred to his recollected experiences of the late 1960s as a 'cherished moment of involuntary realism', opening up issues around art writing which remain pertinent to the practice of art history.
\end{abstract}

Keywords: Art \& Language; Morris Louis; modernist criticism; postminimalism

Between April and May 1969, a twenty-seven-year-old Charles Harrison stood before Morris Louis' Red Go (1962) at the Waddington Galleries in London. Harrison recalled this experience for the first time during a lecture at Tate in 1986 to mark the occasion of Art \& Language's nomination for the Turner Prize (Melvin 2013, p. 154). ${ }^{1}$ He repeatedly turned to it in a number of interviews which have been subsequently anthologized (Melvin 2011).

Harrison reflected upon the experience at greater length in the 2009 essay 'Feeling the Earth Move'. Here, Harrison claimed that in order to be noticed as an emergent critic, it was necessary to 'match your judgments in print against the verdicts of authoritative judges... ' (Harrison 2009a, p. 128). The authorities in question here were Clement Greenberg-who had written 'Louis and Noland' in Art International in 1960-and Michael Fried, who published 'The Achievement of Morris Louis' in Artforum in 1967 (Greenberg 1993a; Fried 1967, 1996a). For the likes of Harrison, those critics appeared to provide a convincing means of evaluation couched in elegant prose. They also offered a distinct protocol of self-cultivation. Put more strongly, Caroline Jones has argued that Greenberg's modernism was a regulatory mode of subjectivity (Jones 2005).

Many years later, in Essays on Art E Language, Harrison (2001a) offered a description of one element of this form of modernist self-fashioning. He had learned, he argued, that through careful attention to modernist criticism, putatively authentic paintings such as those by Louis required a particular mode of address in order to experience them fully. Harrison retrospectively recounted that the task was to 'stand before the work of art, passive, alert, and disengaged from all interests and preconceptions. If emotion welled into the resulting cognitive void, the work was taken to be good' (Harrison 2001a, p. 154). This mode of apprehension is not strictly Kantian, although it does adequately describe the critical positions of the late Greenberg and the early Fried. For Harrison it presupposed Richard Wollheim's 'adequately sensitive, adequately informed spectator' (Harrison 2001a, p. 50; Wollheim 1987). ${ }^{2}$ The corollary was the claim that Louis' paintings, in order to 
exert such an effect upon the suitably receptive viewer, must be 'vehicles of feeling', as Greenberg put it in a catalogue essay from 1963 (Greenberg 1993b). Harrison would later come to realize that those two aspects- the feeling of the viewer, and the painting as a causal mechanism for that feeling-were by no means coterminous, this being one of the main factors in the breakdown of modernist criticism.

Harrison published his review of Louis in Studio International, where he worked part-time as an editor between 1966 and 1971. The influence of Greenberg and Fried is freely acknowledged in Harrison's later recollections, which is evident not only in his careful, descriptive prose, but in his evaluation of Louis' importance (Harrison 1969a, p. 192; 2009a, pp. 128-30). However, Harrison's adherence to what he would later term modernist orthodoxy did not last long. Greenberg's 'Tyranny of the Eye' may have been nasty and brutish, but it was also short-lived. Only months later, Harrison was invited by Philip Leider to write a review on the sculptor Philip King for Artforum. The fee paid for Harrison's first trip to New York (Melvin 2011, p. 33). ${ }^{3}$ During this trip, Harrison met Greenberg and the elder critic recommended that he see Louis' bronze 'veil' paintings in the André Emmerich Gallery. In this new, and for Harrison, unfamiliar context, his previous convictions were shaken. As he reassessed his position, he found that his doubts were not caused by his evaluation of Louis per se, but rather by the determining factors at work in making that evaluation. The experience of Louis on the artist's home soil felt qualitatively different from London. In the U.S., Harrison could not fully shake off a sense of provincialism as an English critic in a foreign city. In the gallery's 'forbiddingly classy' surroundings, Harrison recalls, 'I could not see [Louis' paintings] as art at all. Far from serving as vehicles and expressions of feeling, they had the aspect of wallpapered money, dissolving without remainder into a culture I was feeling put down by' (Harrison 2009a, p. 130). To compound his sense of unease, as Harrison left the gallery and consulted the promotional paraphernalia for the show, amongst it lay his review for Studio International, which displayed the judgment of Louis he was now privately calling into question. He also came to doubt the continued historical validity of abstract painting (Harrison 2009a, p. 134).

Those doubts were reinforced by his experience of Carl Andre's 144 Magnesium Square (1969) at John Weber's Gallery. Despite his commitment to modernism in the late 1960s, Harrison had taken an increasing interest in artists such as Joseph Beuys, Roland Brener, Barry Flanagan, John Latham, and Roelof Louw, who would be grouped under a panoply of terms, the most common being conceptual art and post-minimalism (Harrison 2009b, pp. 40-41). Those diverse interests are evident in the texts written for Studio International during the period, where one finds essays on Jeremy Moon alongside interviews with Latham and favourable remarks on Beuys (Harrison 1968a, 1968b, 1968c, 1968d). Harrison also organized and curated a number of key exhibitions during this phase. He curated a retrospective of Ben Nicholson at Tate Gallery and he installed When Attitudes Become Form at the Institute of Contemporary Arts in 1969. He curated Idea Structures at Camden Arts Centre, and Art as Idea at the Victoria and Albert Museum in 1970. He organized The British Avant-Garde at the New York Cultural Center and Art as Idea from England at the Centro de Arte y Comunicación (Centre of Art and Communication) in Buenos Aires in 1971. For the exhibitions at the Institute of Contemporary Arts and the New York Cultural Center, he published accompanying essays in Studio International (Harrison 1969b, 1971).

From an art-historical perspective, Harrison's dilemma opens up issues fundamental to art writing. First is the extent to which we ought to pay close attention to the art object, and the extent to which it can be explicated by, or differentiated from, theoretical or sociohistorical contexts. As Greenberg's modernism lost its explanatory power, the notion of the art object's autonomy also fell into desuetude. But as Harrison argued in his later writings, a too-easy dismissal of what he and his colleagues in Art \& Language called the 'intension' of the art object overlooked the possibilities offered by a refusal to allow art to disperse into an undifferentiated realm. The notion of 'intension' denotes, for Harrison, certain ascertainable properties which distinguish art from non-art (Melvin 2011, pp. 47-49). Harrison traces it back to earlier modernist notions such as 'Significant Form', but one could also connect 
it to formalist concerns in the 1960s with shape, surface, and esthetic 'quality'. Those concerns were allied to an anxiety towards 'objecthood', or to the mere unbounded nature of experience which threatened to breach, or even destroy the boundaries of careful formalist analysis (Fried 1996d). But for Harrison, the term also applies to what he considered to be the more rigorous forms of conceptual art which sought not to dissolve the category of art altogether but to maintain its internal complexity as distinct from mere 'text' or material stuff in the world. Harrison's collaborators Art \& Language did not regard conceptual art as an easy dismissal of modernists such as Jackson Pollock, but rather a continued working-through of its complexities (Harrison 2001a, p. 180).

If the term 'intension' refers to certain distinguishable properties of an artwork, it is also connected to its homonym 'intention'. This is not the 'intention' of phenomenologists, where the term denotes the mind's directed-ness towards its object. Instead, 'intention' here refers to the art-historical claim that artworks are made or formed with an intention in mind: one which the artist may not be consciously aware of, but which may be retrospectively articulated by the artist, or recovered by the art historian. This idea has been of renewed interest to a number of scholars clustered around the online journal nonsite, such as Todd Cronan and Michael Schreyach (Cronan 2013; Schreyach 2017). ${ }^{4}$ Recently, Sam Rose took issue with the privilege that 'intentionalists' like Harrison accord to the artwork. The formalist's close attention to and analysis of the art object is, Rose argues, always grounded in some kind of originating context of production or reception. Further, he argues that it is one which frequently assumes a simplified notion of artistic intentionality (Rose 2017). A number of Rose's claims are helpful to keep in mind as we proceed. However, a problem which circulates around Harrison's difficulties at the turn of the 1970s is that the issue of context (in this case 'modernism') is not stable or easily defined; nor is the relationship between the art object, its effect, and determining context(s).

This brings us to the final issue attendant upon Harrison's early formation as a writer, which is the emergence of conceptual art and post-minimalism. Harrison later wrote that it remained an open question whether the emergence of those new practices marked 'a change in the historical character of our culture, or merely a redirection of intellectual and artistic fashion' (Harrison 2009b, p. 28). The currently contested notion of 'the contemporary' testifies to the continued after-effects of the cultural changes of the 1960s. In this respect, Harrison's question remains pertinent. Within the scope of this essay, our main interest is how these complexities bear upon the problem of art writing.

\section{Morris Louis}

As an explanation to the reader, Harrison writes that, to those who might have found it 'a bit odd to have regarded Louis as a controversial figure in 1969, I can only plead that this was England...' (Harrison 2009a, p. 128; Melvin 2011, p. 99). Harrison admits here to being somewhat late to the party. Louis' presence is no longer felt in contemporary art; nor does he feature prominently in recent art-historical scholarship (a recent exception being (Curley 2021)). Instead, he is largely regarded as a relic of a bygone era. On the occasion of Louis' retrospective in 1986, Robert Hughes wrote, 'Here is the beautiful impasse ... the eloquent sigh of transparent color that was soon to be a period style' (Hughes 1990, p. 200). Peter Schjeldahl dismissed the painting of Louis as 'an art stamped with "quality" (like prime meat) for consumption by an ambitious class .... [the paintings] produced an intricately evasive criticism with a power to seduce sheltered minds' (Schjeldahl 1991, p. 275). Schjeldahl raises the problematic notion of esthetic 'quality', which in the late writings of Greenberg took the form of mere rhetorical assertion. Schjeldahl also makes the perceptive claim that the strictures of formalism appealed to the insecurity of ambitious young critics and academics. Certainly, the young Harrison admired not only of the criticism in Artforum, but also the cogency of the modernist narrative which provided a historical rationale for its development. This rationale was accompanied by a compelling set of requirements for the proper apprehension of modernist painting. Harrison's engagement with conceptual art and post-minimalism would compel him to call these requirements 
into question, albeit without fully relinquishing them, as he expounded more fully in his later writings (Harrison 2001a).

Although Louis was no longer of interest to advanced artists in 1969, several years earlier, he had been the subject of debate around the issue of chance and composition. This dispute emerged after Louis' death: first, in an obituary in Art News in October 1962, and then more fully in Daniel Robbins' 'Morris Louis: Triumph of Color', published in Art News in 1963 (Robbins 1962). After Louis' death, a number of unstretched and undated paintings were left in his studio. Of such work, Burning Stain (1961) featured in Louis' retrospective at the Guggenheim in 1962. On arrival at the museum, the unstretched painting was accompanied by a note from Louis, stating that 'I have not filled in the size of the picture-I will leave the measurements to you once it is stretched' (Robbins 1962, p. 29). Robbins took this remark to indicate that Louis' relative unconcern with the formal limits of the canvas and his embrace of chance demonstrated an attitude towards painting which was prefigured by Harold Rosenberg's 'American Action Painters' in 1952, where he argued that the Abstract Expressionist gesture obviated conventional notions of style, composition or esthetic quality (Robbins 1962, p. 29). Robbins' argument prefigured in turn the process-based post-minimal work of the late 1960s, theorized in essays such as Robert Morris' 'Anti-Form' (Morris 1968).

Greenberg wrote a letter to Art International in 1965 as a response to Robbins (Greenberg 1993c, pp. 209-12). Drawing on his experience of the artist's studio, he argued that Louis took great care with the color and placement of his waves and sheaves of paint, and that Robbins had misinterpreted the note left to staff. It did not, Greenberg argued, allow museum staff to determine the picture's size and shape. As with other paintings from the period, 'the rolled canvas ... arrived in New York cut precisely to the size and shape in which he intended it to be stretched, allowing for the lap-over needed to secure it to the size of the stretcher' (Greenberg 1993c, p. 210). Greenberg later added, however, that in the stripe paintings such as Burning Stain - which did not contain any crayon marks to indicate the dimensions - compositional decisions 'were always indicated in the paint itself' (Greenberg 1993c, p. 211; Singerman 2003, p. 131). Wily as ever, Greenberg shifted the weight of compositional decision from the dimensions of the painting's surface to the implied relationship between the painted image and its framing edge (Greenberg 1993c, p. 210). This in itself, however, is not straightforward, since, as Greenberg admitted in a later postscript published in 1966, Louis was open to advice from his few close confidants as to how to crop his paintings (Fried 1967). In the case of the 'stripe' or 'pillar' paintings such as Burning Stain, Greenberg and William Rubin had advised Louis to leave spare canvas at the top; although Louis himself preferred to crop through the areas of paint at the top and bottom (this is how Burning Stain was exhibited at André Emmerich Gallery in 1961, although no photograph exists of this installation) (Upright 1985, p. 28). Further, in the case of some stripe paintings, Louis experimented with the orientation of his canvases, even suggesting to a collector that she could hang Apex (1961-1962) horizontally if she preferred (Upright 1985, p. 29). Greenberg's postscript admitted, then, that Louis could change his mind about the cropping and even the orientation of his paintings, but this ambiguity did not imply that Louis was indifferent to the visual appearance of his work, nor that the visual effects were separate from the means of arriving at them.

In his review, the young Harrison declared his allegiance to Greenberg. In a phrase reminiscent of Fried, Harrison rejected what he called the the avant-garde but meaningless concept of "un-compositional painting" attributed to [Louis]'. Such an idea, Harrison continued, was 'irrelevant either to [Louis'] intentions or to his procedures' (Harrison 1969a, p. 190).

\section{Intention}

The debate around Louis, although mired in ambiguity, was to a large extent an argument about intentionality, particularly, the extent to which chance operated in Louis procedure. Harrison held the position that works of art are shaped by the conscious 
intention of their makers. Although similar to Richard Wollheim's claim in Painting as an Art (1987), Harrison also allowed for a kind of retrospective intention, whereby intention is not a prior mental conception of what the artist intends to do; but it can also pertain to what the artist has done (Harrison 1993, p. 209; Melvin 2011, p. 49; Wollheim 1987).

However, in the case of late modernist criticism, the function of criticism and the role of the artist have a tendency to overlap. Fried made the claim in 'Three American Painters' that the modernist critic and the artist were involved in a shared enterprise (Fried 1996b, p. 219). However, the innovations of modernism also presupposed an intentional agency on the part of the artist. The critic's act to some extent recovers this process, a claim made in Greenberg's lecture 'Convention and Innovation' at Bennington College in the 1970s, where the elder critic restyled himself as a homespun esthetician. Greenberg argued that the esthetic quality of a work of art-and the quality of the experience afforded to the viewer-was arrived at:

In some essential part, to the sense gotten of resistances coped with by dint of choices or decisions (intuited decisions or what I call judgment-decisions.) Quality, the very success or goodness, of formal art derives, formally, from these decisions, from their intensity or density. (Greenberg 1999, p. 47)

This intuitiveness is significant to the critic's recovery of Louis' decision-making: It is not simply enough to see the work as deriving from an a priori decision ('I intend the painting to look like this'). Intentionality here makes a claim for the work's appearance as a consequence of decisions made by the artist. Harrison's discussion of Dalet Kaf (1959)which he incorrectly refers to as Kuf, a different 'veil' painting from 1958-works carefully to attempt such a reconstruction:

The unprimed and unstretched canvas must have been suspended at the top, held out at an angle and fixed at the bottom to allow a slight sag; any paint which was not absorbed by the canvas would gather in the trough so formed, from which it could be soaked up with a sponge. The painting appears to have been made in several separate episodes. First: three broad swathes of purple were poured down the canvas, spaced evenly across its surface; second: four swathes of green were run over them, overlapping and combining; third: five swathes of very thin black were poured over these, dulling and unifying the tones beneath, except along the very top of the canvas where the apices of the parabola overlap; fourth: a penetrating wash of pale green was laid over the top half of the image, binding with the other tones and running down into the black. Because the green, which is mixed with white, appears so much more transparent than the dark tones beneath, it seems as if the latter must have been applied last, in which case the black would have had to run upwards into the green. (Harrison 1969a, p. 191)

In this passage, Harrison puts himself imaginatively in the place of Louis at work in order to reconstruct the making of the painting. However, he does not go so far as to intuit the 'rightness' of the decisions, as Greenberg advocated; instead, he adopts a rather dispassionate tone. Michael Baxandall (1979), in his renowned essay 'The Language of Art History' argued that much art-historical description falls into three categories. The first are 'comparative or metaphorical terms' for the visual interest of an artwork, such as 'rhythmic' or 'fugal'. The second are 'causal or inferential' terms which attempt to describe the agency of the artist, i.e., 'sensitive' or calculated'. The third, 'subject or ego words', describe the effect upon the viewer, i.e., 'striking' or 'imposing' (Baxandall 1979, pp. 457-58). Notably, Baxandall draws these terms from Heinrich Wölfflin's descriptions of Raphael's Camera della Segnatura in Classic Art (1899). Louis' painting is hardly comparable, and interestingly, Harrison's terms do not map very easily on to Baxandall's categories. One could describe them as largely operative within category two, except that Baxandall's 'causal' terms are metaphorical and qualitative; i.e., the artist is 'sensitive' or 'virtuosic'. Harrison's causal terms are largely descriptive of the processes of pouring and staining that he imagined Louis to have undertaken. They are still metaphorical, but in a weaker sense. Baxandall's 
third category, 'subject and ego' terms, are perhaps most appropriate to the language of modernist criticism, especially with regard to the affective quality of the work upon the beholder. In Harrison's passage, this last term only applies to the concluding section, where he notes that despite Louis having poured paint down the canvas, the effect is one of upward movement: It 'seems to be anchored at the base and to sweep up from it like a wave breaking upward against the foot of a cliff' (Harrison 1969a, p. 191). This sense of vertical ascension was explicated in more effusive metaphorical terms by Fried as a kind of 'soaring or release' in Frank Stella's Irregular Polygons (1966-1967); Harrison's account of Dalet Kaf lacks the élan of Fried in full flight, although one might argue that it allows us to see more clearly the workings of modernist criticism and its underlying assumptions (Fried 1996c).

Harrison's passage might be said to lack something of what Svetlana Alpers called a 'motive for looking', an expression which Fried, in a recent dismissal of Baxandall's argument, rephrases as a 'motive for describing' (Alpers 1976; Fried 2016). With this in mind, we could point to the absence of a theoretical armature for Harrison's description, or of a motivating impulse which drives that description. At that point, the young writer looked to the modernist context in the U.S. with admiration and even envy, but he was not a part of that context. He had no particular investment in Louis beyond his desire to make a career as a critic. As a result, Harrison's text appears as a dutiful following of modernist protocols. This helps to explain, at least partly, Harrison's 'humiliating and confusing experience' of Louis at André Emmerich. He recalled that, 'It was not that I was sure I had been wrong about Louis. The point was that I could no longer be sure that the work itself had been responsible for my conviction of its value [my emphasis]' (Harrison 2009a, p. 131). Harrison claims that he felt the quality of Louis' work in the Waddington Galleries, but his experience in New York caused him to doubt whether that experience was directly caused by the work, or whether it had been a function of certain other cultural or historical factors. The remark also suggests that the relationship between the work 'itself' and its armature-whether that is institutional or critical—can no longer be neatly picked apart. In this sense Rose is helpful here. He writes:

... there is no question of secure visual analysis without some idea of a context of origin or reception that will decide what the work really 'is'. In this sense we are always dealing with preferred forms of what might constitute a disambiguating context, rather than any neatly internal/external, text/context, situation. (Rose 2017, p. 15)

Following Rose, we might seek to understand Harrison's dilemma, which he later called 'the beginning of the end of my intended career as a critic', as providing an instance of the different kinds of contexts in play when we write about artworks (Harrison 2009a, p. 131). Modernism, as Rose has argued, is one such context, and Harrison's crisis over Louis brought this into view. We might argue that the language of modernist criticism remained transparent for as long as it seemed to 'fit' as a credible account. However, once modernism's hegemony was challenged by emergent practices, opponents claimed that its language came more fully into view. This is a problem Harrison acknowledges after his encounter with Art \& Language, whose various members he met between 1969 and 1970 (Melvin 2011, pp. 136-37). The period following his trip to New York entailed a great deal of rethinking around modernist assumptions of autonomy and the self-evident quality of its artworks. To stand back in front of a Louis and to feel that quality was no longer a tenable proposition. Instead, the parameters shaping the work demanded both historical understanding and critical exploration. In a sardonic retrospective remark, he recalled that 'I had a difficult couple of years [roughly 1969-1971] while I tried to fool myself that I could get round the problem by sponsoring a different kind of art' (Harrison 2009a, p. 133). It is worth considering these years more closely since they form an important facet of the problem of writing and its relationship to the surrounding structures hinted at in his (re)experience of Louis. The new work of Andre, Flanagan, Kosuth, and others appeared to move 'beyond' the modernism of Louis since it appeared so radically different. However, 
Harrison would later come to doubt this radical rupture. For now, however, it is important to consider those crucial years.

\section{3. 'When Attitudes Become Form' (1969)}

Harrison's next piece for Studio International was entitled 'Against Precedents', which accompanied the landmark exhibition When Attitudes Become Form (Harrison 1969b). This iconic show, displayed at the Kunsthalle Bern between 22 March and 27 April 1969, was curated by Harald Szeeman, a talismanic curatorial figure, even if he referred to himself as an Ausstellungsmacher (exhibition-maker). Harrison helped to install the show at ICA, which ran from 28 September to 27 October 1969. In Attitudes, artists were invited to 'intervene' in the space of the Kunsthalle Bern, rather than have their work selected and installed for the space. This is central to the exhibition's significance, since the exhibiting artists were similar to contemporaneous shows such as Op Losse Schroeven (1969).

Harrison's enthusiasm for many of the artists did not extend towards Szeeman, whom he later referred to disparagingly (Melvin 2011, pp. 49-50, 114-16, 164-65). Instead of showing the artists in the best light-a more old-fashioned idea of the curator's roleSzeeman prefigured the role of the celebrity curator, where the artists are orchestrated according to his premise, and the curator takes on the cultural prestige of the artist (Celant 2013, p. 453). ${ }^{5}$ In December, Harrison interviewed Seth Siegelaub, an experience which only reinforced his disillusionment with curating and his antipathy towards a new kind of curator, and what he later regarded as an opportunistic consequence set in train by conceptualism (Harrison 1969d; Melvin 2011, pp. 40-42).

As for the accompanying essay, 'Against Precedents', Harrison later described its language as 'ghastly', in particularly the opening line: 'Art changes human consciousness' (Melvin 2011, p. 133; Harrison 1969b, p. 90). The text contains a number of grand, sweeping claims. However, Harrison's remarks were not dissimilar to those of Szeemann. In an interview to accompany the exhibition, the curator expressed his desire that the exhibition transmit 'une prise de conscience' (Belilose and Gazut 1969). Further, Szeemann added that the 'form' of the exhibition's title referred to the artist's capacity to act out the artist's existential situation: this 'gesture' enlarged our understanding of possibilities in a given context. Harrison made a similar claim in his text (Harrison 1969b, p. 91). One might think here of some of the celebrated interventions made during the show: Michael Heizer's Depression (1969) or Cement Through (1969)—which used a wrecking ball outside the Kunsthalle-Richard Serra's Splash (1969), or Daniel Buren's affichages, which were not part of the show, but came to be associated with it, since he posted his signature stripes in and around Bern. While Serra's sedimentations of poured lead might recall the gestures of the Abstract Expressionists, Heizer's and Buren's were gestures of a different kind, the latter one which Harrison would later take issue with, as we shall see.

The major change in Harrison's writing in comparison with the Louis review is that throughout 'Against Precedents' there is scant reference to specific artworks, save for a few brief remarks upon Carl Andre and Joseph Kosuth. Andre is praised for having used material in opposition to its economic value or function, and Kosuth for his non-literary use of language (Harrison 1969b, p. 91). However, these brief remarks are a long way from the careful attention paid to Dalet Kaf a few months earlier.

Harrison also couched much of the work in Attitudes in modernist terms, arguing that the force of the work to effect change was necessitated by the need to distance itself from current social and cultural conditions. Further, he added that the difficulty of much of the work on display could be explained by its practices of negation. Most significantly, he added that 'virtually all the artists represented would appear to share a dissatisfaction with the status of the artwork as a particular object in a finite state, and a rejection of the notion of form as a specific and other identity to be imposed upon material' (Harrison 1969b, pp. 90-91). This idea chimes with the writings of Robert Morris during this period. It also reflects Harrison's interest in the work of John Latham and Barry Flanagan, both of whom Harrison had befriended, and published on during this period. Further, unlike 
Louis, who was a painter, the overwhelming tendency in Attitudes was towards work in real space. As Harrison later noted, 'It seemed that "sculpture"—or "three-dimensional work" - had prised itself conceptually loose from painting, leaving the latter to fulfil a highly specialized and possibly redundant esthetic function' (Harrison 2009b, p. 43). This notion of 'redundancy' reflects the views of Joseph Kosuth, whom Harrison met during his visit to New York in 1969. He invited Kosuth to write the essay 'Art After Philosophy', which was published in three parts in Studio International between October and December 1969 (Kosuth [1969] 1991; Melvin 2013, pp. 159-74). Although controversial, and a position Harrison would not fully agree with, Kosuth's argument that the 'conventional' media of painting and sculpture were no longer sufficiently philosophically reflexive, appeared to lend credence to the kind of works which Harrison was advocating at the turn of the 1970s.

Harrison was involved in organizing a number of key shows in this respect. In 1970 he organized Idea Structures at Camden Arts Centre, which showed the work of Keith Arnatt, Victor Burgin, Ed Herring, Kosuth, and the early members of Art \& Language: Atkinson, David Bainbridge, Baldwin, and Harold Hurrell. Harrison later claimed that it was the only show he organized that he was satisfied with (Melvin 2011, p. 148). One can infer from this that the show best exemplified the works of the artists without any intervening institutional or personal compromises hampering the show. Harrison also worked with Siegelaub on a special issue of Studio International in the July/August issue. Those shows intimated Harrison's later preference for conceptual art over the more ostensibly materially-based practices of post-minimalism and Arte Povera. However, in addition to those curatorial initiatives, two essays published in Studio International in 1970 bring Harrison's critical dilemma into relief. The first is Greenberg's 'Avant-Garde Attitudes: new art in the sixties', published in April. The second was a rebuttal from the Australian academic Donald Brook in the September issue.

Greenberg's essay was initially a lecture delivered in Sydney in May 1968 as part of the John Power Lectures in Contemporary Art. Although not republished in any subsequent anthologies, the argument is in line with attacks on 'novelty art' elsewhere in his late criticism. 'Novelty art' was Greenberg's problematic catch-all rubric which included Assemblage, Marcel Duchamp, Minimalism, Pop Art, and the plethora of practices which did not fit into his historical dialectic of modernism. Greenberg upheld 'taste' as the compass to navigate through the confusion which he argued was caused by art's proliferation into a variety of new practices. 'Taste' also separated the authentically avant-garde from the merely adventitious or banal. This latter category comprised Greenberg's familiar arch-enemy Duchamp and his followers. In a capricious move, the category also included the Milky Way. Greenberg claimed that our vast and sublime galaxy, when viewed as art, was simply 'banal' (Greenberg 1970, p. 145).

The response from Brook in September was forceful. Brook was associated with Terry Smith and the exhibitions of Art \& Language in Australia and New Zealand in the mid-1970s (Bailey 2016). For our purposes, however, his essay raised a number of issues germane to Harrison's concerns. Brook argued that the frequent appeal to Greenberg's 'resounding platitudes' ('as Greenberg has argued ... ' etc.) which one found in the art press could only rest upon an unthinking deference to authority. Brook made four claims. First, that art history did not evolve in a linear fashion; second, that 'formal' analysis was not uniquely equipped to the task of art criticism; third, that esthetic judgments were not objective. Finally, he dismissed Greenberg's claim, paraphrased by Brooks, that 'there is only one linear scale of esthetic excellence, and each work of art possesses so many degrees of goodness on this scale' (Brook 1970, p. 66).

On the issue of formalism, Brook noted that 'formal' criticism is mysterious to the extent that 'nobody has succeeded in giving an acceptable account of how we are to recognize those statements about a work of art that refer to its form; and how we are to distinguish them from those that do not' (Brook 1970, p. 67). This claim prefigures Rose's recent argument. A second point by Brooks is more important still. This is that language and learned behavior play important roles in the formation of esthetic experience 
(Brook 1970, p. 68). Those ideas were of especial importance to Harrison for the rest of his career: He has remarked upon the fact that the practice of Art \& Language had an educative bent which goes back to the Index in 1972, which encouraged active reading and learning on the part of the gallery-goer.

In November 1970, Harrison published 'A Very Abstract Context', another essay which caused him later embarrassment. Here, he attempted to provide a rationale for the historical insufficiency of current abstract painting, and in it, he makes an argument in favour of the new artists he was championing, such as Kosuth, Lawrence Weiner, and Art \& Language. Stylistically, Harrison's prose is reminiscent of Fried, but the sensibility and the argument owe much to Kosuth's 'Art After Philosophy'. Harrison claims that there is a certain conceptual or philosophical insufficiency in all but the very best contemporaneous abstract art. He understands 'abstraction not as the visual characteristic of a range of objects ... but as a faculty of thought, a condition of consciousness' (Harrison 1970, p. 195). Consequently, the notion of the 'abstract' could encompass work such as Kosuth's One and Three Chairs (1967), or Art \& Language's Lecher System (1969) exhibited in Idea Structures. This latter work was accompanied by an Art \& Language text in the special issue of Studio International in summer 1970. Here, two fictional interlocutors, accompanied by an alien, discussed the possibility of invisible radio waves as a viable form of sculpture, and whether said sculpture was amenable to art-historical analysis. The alien, on the other hand, could see the radio waves, but was uncertain as to the function of what we earthlings call 'artists'.

Elsewhere in 'A Very Abstract Context', Harrison cited Kosuth's claim that conceptual art bypassed the function of the critic as a mediator between artist and audience. This claim is correct to the extent that conceptual art marked a historical moment where a particular kind of criticism lost its authority. The implicit claim, however-that conceptual art did not require any kind of mediating or evaluative criticism to render it legible-is more dubious. In another Kosuthian move towards the close of the essay, Harrison inserted a sequence of quotations from A.J. Ayer, Burgin, and Latham: each quote referred to the dispensability of the 'object', either as a philosophical concept, or as necessary condition for an artwork (Harrison 1970, p. 157).

Soon after the publication of the essay, Atkinson and Baldwin visited Harrison at home for the first time. On entering, Baldwin greeted Harrison by declaring, 'Your article was a load of crap' (Melvin 2011, pp. 136-37). To Harrison's surprise, Atkinson and Baldwin were uninterested in the mere fact that he praised their work. They were concerned with the quality of his argument, which Harrison took as a sign of integrity. Baldwin's insult, recollected in tranquillity, marked the beginning of a long-standing collaboration.

\section{4. 'The British Avant-Garde' (1971)}

In 1971, Harrison organized the exhibition The British Avant Garde, which was held at the New York Cultural Center between 19 May and 29 August. The show was a joint effort with the issue of Studio International in May 1971, where some of the artists' works were also published, alongside Harrison's catalogue essay, 'Virgin Soils and Old Land'. This show included a number of works which, in retrospect, have come to be recognized as canonical. Indeed, some were re-exhibited at Tate Britain's recent show Conceptual Art in Britain: 19641979 (2016) which was curated by Andrew Wilson. Works reproduced in Studio International included Keith Arnatt's I Have Decided to Go to the Tate Gallery Next Friday (1971), Bruce McLean's Their Grassy Places (1969), and David Tremlett's Tap Piece (1970). Other artists included Atkinson and Baldwin, Burgin, Flanagan, and Richard Long. As Melvin has outlined in extensive detail, Harrison's experience of the organization and installation of the show was difficult. Partly, this was due to Harrison's relationship with Donald Karshan, the Center's founding director (Melvin 2011, pp. 143-44; Melvin 2013, pp. 174-91; Melvin 2016). However, there were also a number of practical problems involved installing work made from non-conventional media.

For instance, Flanagan's ringn (1966) consisted of a tonne of dry sand poured directly onto the floor. Four scoops were to be made into the top of the 'cone' of sand, which were 
then tipped down the sides of the sculpture. As Melvin notes, Flanagan made a film-no longer extant-entitled The Lesson, which demonstrated how to construct the work (Melvin 2013, pp. 183-84). Melvin adds, however, that Flanagan required a specific type of builder's sand. This was a fine dry sand entitled BS19, sourced from J. Arnold Builder's Merchant in Leighton Buzzard (Melvin 2013, p. 182). This was not so easily sourced in New York where Harrison was not familiar with the building trade, a matter compounded by the fact that he had no access to office facilities while Karshan was away on other business. This happened after Harrison had just flown into New York from Buenos Aires to install the show Art as Idea from England. He later recalled that his marriage broke down during this period (Melvin 2011). Clearly, the cluster of problems he experienced, such as his distaste towards curating, his aborted career as a critic, and his disillusionment with the artworld, is heavily over-determined. However, nonetheless, despite this complexity, there is an art-historical aspect which is of particular interest. This is the move towards 'post-object' art and the related problem of writing.

Harrison had great difficulty finding the correct sand for ringn. To add to the indignity, he then had to shovel the sand for a related Flanagan piece in the Manhattan heat (Melvin 2011, p. 144). Those physical exertions contrast with the immaterial labor of his role as a critic earlier the same year:

... the most simple, the most extreme and the most poetic sculpture in which [Flanagan] has expressed these concerns [of process] is $\operatorname{RingN}$, a sculpture made by pouring dry sand, exhibited in his first exhibition at the Rowan Gallery in August 1966... . Like Roelof Louw, Flanagan avoids imposing his will upon the materials he uses in order to transform them to his own ends, seeking rather to establish a situation in which his identification with materials and processes is assured and unassertive from the start. (Harrison 1969c, p. 30)

This 'unassertive' attitude was indicative of a more localized reaction against the influence of Anthony Caro and his epigones at St Martin's School of Art. But it formed part of the broader turn away from formalist modernism. Although Louis' work involved processes which initiated debate between Greenberg and Robbins, this particular debate could not arise with Flanagan, since the piece can be re-created without the presence of the artist (although in Harrison's case, this re-creation was more physically arduous than one might assume). Consequently, although the work is not conceptual in the strict sense, it lent itself to the notion of 'dematerialized' or 'post-object' art which was prevalent amongst artistic practice, but which was also articulated in a series of essays written in Studio International at the turn of the 1970s.

\section{5. 'Virgin Soils and Old Land' (1971)}

'Virgin Soils and Old Land' was Harrison's first essay to have been read and commented upon by Baldwin and Ramsden. Despite this, it is arguable that it is any more successful than 'A Very Abstract Context'. A meandering, convoluted piece written in a somewhat stuffy tone, the text, unlike 'Against Precedents', mentions no artworks at all. Taking his cue from the combative tactics of Art \& Language, Harrison leveled a broadside against various art world factions. Patrick Heron was attacked for his 'formal archness'. The Independent Group were scolded for their 'rapid decline into failure and frivolity'. More indiscriminately, abstract painters were accused of working out 'vacuous images' as if they were writing an Agatha Christie pot-boiler (Harrison 1971, p. 201).

More substantively, Harrison raised the issue of Caro, whose sculpture had turned out to mark the end of a particular modernist tradition, rather than the beginning of a new one, as his critical supporters had claimed. The ghost of Caro haunted the direction of English art at the turn of the 1970s, which had split into two factions. This was characterized by Harrison as a split between what he termed 'uncritical loyalty versus ignorant avantgardism' (Harrison 1971, p. 202). That is, on one side, a fealty to modernist formalism which failed to adequately question its own presuppositions. On the other, a position not dissimilar to Greenberg's 'Novelty Art', a form of self-conscious radicalism which Harrison 
referred to elsewhere as exemplifying the more 'whimsical and extravagant' variants of conceptualism (Harrison 1972, p. 234). Years later, Harrison called this 'a tradition of avantgarde gambits', such as those by Duchamp, Piero Manzoni, and Francis Picabia (Harrison 2001b, p. 63). This 'avant-gardist' attitude is characterized by a remark from Kosuth [1969] (1991) in 'Art After Philosophy': 'if [Jackson] Pollock is important it is because he painted on loose canvas horizontally to the floor. What isn't important is that he later put those drippings over stretchers and hung them parallel to the wall' (Harrison 2001b, p. 63). Kosuth argued that our interest in Pollock resides not in his capacity as a painter, but rather in his adoption of novel or unconventional means with which to paint, thus providing a license to go beyond an allegedly exhausted tradition. This split between a modernist privileging of the esthetic against a putatively anti-esthetic 'avant-gardism' is also relevant to the debate around Louis we discussed earlier. The debate turned on whether Louis' pourings were 'intentional' and authentically modernist or proto-post-minimalist in their embrace of contingency. Harrison's position is interesting here, in that, like his colleagues in Art \& Language, he did not fully subscribe to either position. He was a modernist critical of modernism. But he was also a devotee of conceptual art critical of Duchamp and of many celebrated instances of conceptualism.

This distinction between the 'modernist' and the 'avant-gardist' mapped onto a debate between 'object-based' art which was aggressively defended by critics such as Andrew Forge and painters such as Jeremy Moon, and on the other, the notion of 'post-object' or 'dematerialized' art: both terms which Harrison and his Art \& Language colleagues found deeply suspect (Forge 1971; Moon 1971). The issue, as Harrison argued, was not one of whether works of art may be objects or not-Flanagan's sculpture was still an object, after all-but rather the problem of formalist or morphological criteria to evaluate those artworks (Harrison 1971, p. 203).

The difficulty of this matter is helpfully summarized by the opening line of the essay, taken from the Oxford English Dictionary. It states: 'The essence of farming on virgin soils is extension; on old land it is intension' (Harrison 1971, p. 210). The category of extension includes all objects of the same kind: i.e., a list of all the objects which we call 'art'. Intension, on the other hand, describes the properties which an object needs to possess to be included in that category, i.e., the properties which are required for an object to qualify as a work of art. The recent work which Harrison had been championing through the exhibitions between 1969-1971 called this distinction into question, and indeed it is difficult to argue that it is clear and unequivocal. However, Harrison would come to argue that for works of art to be critically significant, it was necessary that some form of 'intensionality' needed to be operative if the work were not merely to disappear into its surrounding social or institutional structures, or even, into the 'dematerialized' ether. In summer 1971, two articles in Studio International crystallized this issue regarding controversies at the Guggenheim involving Daniel Buren and Hans Haacke.

\section{Hans Haacke and Daniel Buren: Transparency}

Two arguments stemming from the notion of a 'post-object' artistic practice were put forward by Arthur Danto and George Dickie. Although subtly distinct, the two arguments are conflated by Harrison, who ascribed to both the claim that artworks are not defined or even recognised by their intrinsic properties but are designated as such by relevant determining contexts or communities (Danto 1964; Dickie 1974). The accompaniment of institutional theory, termed institutional critique, conceives of art as forming part of a seamless, wider context of signification. Hans Haacke's 'Statement' from 1974 outlines this understanding of the artwork. He claimed that:

Products which are considered "works of art" have been singled out as culturally significant objects by those who at any given time and social stratum wield the power to confer the predicate "work of art" onto them; they cannot elevate themselves from the host of man-made objects simply on the basis of some inherent qualities ... In order to gain some insight into the forces that elevate 
certain products to the level of "works of art" it is helpful ... to look into the economic and political underpinnings of the institutions, individuals and groups who share in the control of cultural power. (Haacke 1974, p. 63)

Haacke's Shapolsky et al. Manhattan Real Estate Holdings, a Real-Time Social System, as of May 1, 1971 (1971) became a subject of controversy when it precipitated the cancellation of Haacke's proposed exhibition at the Guggenheim in April. The details were outlined in 'Gurgles around the Guggenheim'. This exchange between Haacke and the museum's Director, Thomas Messer featured in the June issue of Studio International (Buren et al. 1971). Haacke had patiently unearthed and then dispassionately presented information regarding various slum estates in New York City and their ownership via shell company holdings. For supporters of institutional critique, Haacke earned his critical credentials through the subsequent cancellation of the exhibition. This was initiated by concerns amongst Messer and the trustees that the museum could face legal action by the individuals named in Haacke's piece. The cancellation appeared to validate the artist's claim that his practice worked to reveal both the fictitious nature of the museum's neutrality, and the complicities between the museum and its wider contexts (Reise 1971; Deutsche 1986). Nevertheless, despite Haacke's consummate conceptual esthetic of deadpan black-andwhite photography juxtaposed with text-based information, it is by no means clear that, if a libel case had been brought about, the argument for his depersonalized esthetic would have stood up in court. It is fairly clear that despite the deadpan presentation, Haacke's intention was clearly to expose malpractice amongst the individuals named.

In a late essay, Harrison argued that there was nothing wrong with Haacke's intention, which had the laudable aim of drawing attention to injustice and exploitation. It also laudably drew our attention to the complicities of art institutions. Instead, Harrison claimed that institutional critique's practice came at a cost. This being that, 'however unimpeachable its political credentials may be, it runs the risk of buying its effectiveness at the price of transparency-and thus of sentimentality in its interpretation if not its conception' (Harrison 2009c, p. 153). He argued that Haacke's strategy of 'unveiling' structures or relations relies upon the notion of transparency. The contentious aspect of this claim is that sentimentality is the consequence of 'reading off' Haacke's content too easily. Following this line of argument, Haacke finds himself in the unlikely company of Luke Fildes. Fildes' $A n A l$ Fresco Toilette (1889) illustrates Harrison's late essay 'Keeping Up' (Harrison 2009e, p. 185). But as Harrison also notes, Fildes' The Doctor (1887) was derided by earlier modernist critics. Fildes' transparency is distinct from Haacke's to the extent that the depiction of the local doctor-who attends to a sick child with a furrowed brow and kindly attentivenessis less a truthful depiction of actual medical practice, and more a presentation of how doctors might like to see themselves as caring 'patient-centered' practitioners (Moore 2008). Haacke's transparency, on the other hand, aims at the revelation of truth in the demystifying tradition of modernist critique. Rose argues that the reason Fildes' painting is so despised is due to the fact we have such a comprehensive knowledge of its context and likely reception (Rose 2017, p. 5). On the other hand, 'puzzle paintings' such as Giorgione's Tempesta (1506-1508) exert their enigmatic charm precisely because we know so little about their context(s). The Giorgione therefore lends itself to the modernist taste for ambiguity. However, another way of looking at this is to claim that the Fildes painting does not offer sufficient resistance to its contexts. The same could said for Haacke, in that once we have absorbed the content regarding malpractice and institutional complicity, little remains. The work runs the risk of being a mere 'signpost' to broader issues and tendencies (Harrison 2009a, p. 138). Elsewhere, Harrison argues that 'sentimental' art exhibits a tendency to 'manipulate the appearance of emotion so as to coerce the responses of others....' (Harrison 2009e, p. 184). While this might seem more easily applicable to the painting of Fildes, Harrison implies that this coercion also applies to the politically-motivated art of Haacke, in the sense that the work leaves little ambiguity.

Harrison advocated instead for an art which resisted an easily legible interpretation and the potential emotional manipulation of the viewer. As noted at the outset, the notion 
of 'intension' referred to the qualities that distinguish art from mere objects. This distinction maintained certain critical boundaries, protecting the artwork from its dispersal into its surrounding contexts. As we also noted, the term is related to 'intention'. Harrison advocated for the work of art as 'an intensional object ... that reveals its own specific ramifications' (Harrison 2009d, p. 105). 'Intensional' work refuses be 'read off' as content by maintaining some degree of esthetic indifference; but in terms of conceptual work, Harrison claims that its aim was not reducible to either institutional theory or to the grand Duchampian gesture of artistic nomination (i.e., 'it's art because I say it is'). This latter notion could be applied to Buren's cancelled piece at the Guggenheim in October 1970, where a large textile hanging in the artist's signature stripes would sweep down into the Guggenheim's spiral structure. This gesture would effect a transformation of the space while simultaneously making viewers more conscious of the nature of that space as conceived by Frank Lloyd Wright. In Studio International, Buren outlined his rationale in a sophisticated and articulate manner (Buren et al. 1971). Nonetheless, Harrison argues that the stripes are too easily read as signifying 'Daniel Buren' (Melvin 2011, pp. 170-71). The dramatic act of display threatened to upstage the other artists (especially the notoriously prickly Donald Judd). This scale of the gesture is at odds with the otherwise depersonalized and unassuming nature of much conceptual and post-minimal practice.

Although many commentators understand the shift from formalist modernism to post-minimalism as marking a clear boundary, the position of Harrison brings the painting of Louis into alignment with the new practices in one key respect. Harrison argues that Louis' painting shared something with the Art \& Language piece Sunnybank (1968): which is a twenty-eight-page typescript of dense philosophical prose. Harrison wrote of those two works as having something in common:

They were not hanging about the artworld waiting to have the status of art conferred on them and thus, as it were, to discover where their boundaries fell. They were in a sense indifferent to the mechanisms of that conferral. (Harrison 2009a, p. 141)

Sunnybank, although a text-based piece, does not, according to Harrison, function as a piece of text-as-readymade, where an identifiable text-in this case a philosophical one-has simply been re-contextualized as art. Instead, Art \& Language texts functioned as neither art nor philosophy: or perhaps alternately, of art and philosophy. As Michael Baldwin put it, 'it was art in case it was taken to be philosophy, and philosophy in case it was taken to be art' (Harrison 2009a, p. 141). The distinction between the two is never entirely secure. It is this play between the instability of the artwork and its contexts which Harrison argues for, instead of assuming a relatively stable legitimating context—such as the 'artworld' or the institution-which confers art status upon the uncertain object. Nonetheless, this ambiguity means that the notion of 'intension' is never accorded a stable definition in Harrison's writings. In the case of Sunnybank, 'intension' signifies an ontological ambiguity, where the viewer/reader must work to recognize the nature of the text. However, elsewhere, Harrison refers to Gwen John's Seated Woman (The Precious Book) (c.1919-2020) as exhibiting a reciprocal subjective interiority between the depicted figure and the viewer - similar to, although distinct from Fried's 'absorption' — which could be aligned with the 'indifference' noted above (Harrison 2009d, p. 112). 'Intension' takes on a further inflection in the introduction to 2001's Conceptual Art and Painting, where Harrison sets out three the different kinds of relation between art and writing: first, writing as documentation-for instance artist's letters or diaries; second, art as literature-which might include the likes Wyndham Lewis' Tarr (1917); finally, writing as art (Harrison 2001b, p. 3). It is this last notion which interests Harrison, since it accords with the practice of Art \& Language. However, he claims that this last claim for 'writing' is not restricted to conceptual, or text-based work. He also claims that artworks themselves may possess an 'essay-like' quality, referring to Rembrandt's Self-Portrait (1665) in Kenwood House, which addresses an imagined viewer in a manner analogous to an essay addressing an imagined reader (Harrison 2001b, p. 8). 


\section{The Problem of Writing}

The year 1971 marked an important juncturefor Harrison. He took over the editorship of Art-Language. This marked the end of his editorial tenure at Studio International, where he would publish only three more essays, the last appearing in 1974. He would not be involved in any more exhibitions until 1985, when he curated a Ben Nicholson show with the Scottish Arts Council. Significantly, he would not visit the U.S. for another twenty years. But as is well-known, he would go on to serve a long and distinguished career as an art historian at the Open University. However, those two years between 1969 and 1971 would continue to be formative of his thinking, in ways that remain of interest to us as art historians, including those of us who have no desire to engage in practice, conceptual or otherwise.

Looking back from the early 2000s, Harrison returned to the experience and reexperience of Louis. It stood for a broader sense that the ground was shifting under his feet, as Eugene Delacroix had written in his diary in 1857 (Delacroix 1998, p. 331). Harrison framed this recollection with the following passage:

I suspect that most of those professionally interested in the history of recent art have tended to fix on certain autobiographical moments by means of which to connect remembered changes of purpose and self-image to what appear with hindsight as larger cultural and historical developments. Viewed in the selfenchanting light of retrospect, those are our cherished moments of involuntary realism. (Harrison 2009a, p. 128)

As we have seen, this period of Harrison's life, and the broader art-historical context is over-determined by a number of related shifts. Those include the transition from formalism to 'theory' and the broader shift from modernism to post-modernism, compounded by the equally contested term 'the contemporary'. All of this is rendered more complex still by Harrison's later retrospection of his own investment in those earlier historical moments. His reference to 'involuntary realism' indicates that our recollections continue to be formative of our present selves. Since our minds are constitutive of experience, with each recollection, our memories are subtly re-constructed, and become entwined with our other experiences.

Harrison is not the only writer to be imbricated in the transition away from formalist modernist criticism. Nor is he the only writer to re-assess his implication in histories of late modernism. Rosalind Krauss, for instance, made her 'break' with the influence of Greenberg in 'A View of Modernism' (1972) (Krauss 2010). Here, Krauss argued that she was 'still a modernist critic, but only as part of a larger modernist sensibility' (Krauss 2010, p. 128). In 2000, she expressed dissatisfaction with the notion of the 'post-medium condition': a dissatisfaction which chimes with Harrison's (Krauss 2000). More recently, she has written on Willem de Kooning (Krauss 2015). This might seem an unlikely subject for Krauss, given that de Kooning embodied the earlier, 'heroic' modernism which October would critically interrogate. Further, de Kooning's painting was accompanied by the criticism of Thomas Hess and Harold Rosenberg, which Krauss, as with other formalists, disparaged as a florid, 'psychologizing whine' (Krauss 2010, p. 121). Krauss, as with Harrison, occupies a position which may be designated as formalist, but like Harrison, her own relationship to formalism is over-determined. It would be too simple to describe Krauss' career as a mere rejection of formalist modernism in favor of a brave new world of post-modern play.

Another relevant comparison is Michael Fried. If Harrison traced a formative rupture to the encounter with Louis in 1969, for Fried, 1967's 'Art and Objecthood' marked an end to his regular criticism of contemporary art (Fried 1996d). Fried, however, has never relinquished his modernist convictions, even if his distinguished career as an art historian has taken him far beyond the historical parameters of his early writings (Fried 2008, 2010). Harrison admired Fried and was sympathetic to the critique of 'theatricality'. Harrison argued that Fried's polemic against the 'theatrical' was 'not so much to protect the sanctity of the medium as to preserve the ethical autonomy of the work of art and its technical 
concerns' (Harrison 2001b, p. 14). This notion of 'ethical autonomy' is not dissimilar to Krauss' later thoughts on the idea of post-medium (Krauss 2000; Costello 2012; Butler 2020). It also provides a gloss on Harrison's intriguing use of the term 'intension', in that it designates a degree of running-room for art without collapsing it into an undifferentiated state. Nevertheless, what distinguishes Fried is his remarkable self-assurance, which is distinct from both Krauss' and Harrison's conflicted relationships to formalism and modernism.

At the turn of the 1970s, Harrison, as with Krauss, became disenchanted with the underlying presuppositions of formalist criticism, and he championed a new cohort of artists who we now place under the rubrics of conceptual art and post-minimalism. One historical account, which Harrison rejected, is that the intuitive modernism of color-field painting and its accompanying rhetoric of 'quality' and 'feeling' was displaced by new forms of radical practice accompanied by a confident theoretical armoury. Harrison came to question this account when the forms of conceptualism, post-minimalism, and institutional critique, which initially challenged the gallery and museum system, were assimilated by those institutions (Harrison 2001a, p. 46). This transition, once thought to mark a shift from modernism to post-modernism, has since been rethought by numerous commentators. Among them, John Welchman has argued that the rift between modernism and an increasingly dispersed field of artistic practice involved a negotiation between formalists and anti-formalists over what he calls the 'production of a discourse of limits and transgression' (Welchman 1992, p. 35). As Welchman has also argued, the breaching of the self-imposed boundaries of formalist criticism may also involve the constructions of new kinds of 'frame'. For instance, institutional critique produced a social 'frame', while in Allan Kaprow's Happenings the artist 'frames' structured experiences in a radical act of découpage (Welchman 1996, p. 206). This tension between the bounded and the un-bounded, between art and non-art, between criticism and the academy, is at the heart of this broader crisis of late modernism, and indeed, to modernism as a whole. As Welchman also argues, the recognition of art's institutional framing was not an innovation of the 1970s. What was new was the emergence of a persuasive theoretical rhetoric (Welchman 1996, p. 220).

Harrison's recollections might be regarded as specific to debates around modernism and its aftermath, but what was also at stake in his encounter with Morris Louis was the more fundamental issue concerning our attempts to articulate our experiences of artworks. To close, it seems fitting to end with the following question posed by Harrison in his introduction to Greenberg's Homemade Esthetics. He asks:

... are our judgements about works of art corrigible in terms of what we may have to learn about the conditions of their production and about the conditions which they may somehow in turn reproduce? Or are our intuitive responses to art the means by which history is made most vividly present to us, guarding us against the sentimental self-images and spurious certainties of our politics and our morality...? (Greenberg 1999, p. xxvii)

Funding: This research received no external funding.

Institutional Review Board Statement: Not applicable.

Informed Consent Statement: Not applicable.

Data Availability Statement: Not applicable.

Conflicts of Interest: The authors declare no conflict of interest.

\section{Notes}

Charles Harrison, 'Why Art \& Language?' lecture at Tate Britain, 14 November 1984. Tate Audio Visual Collections 457A.

Harrison frequently uses this phrase. See also Harrison (2001a, pp. 54-55, 57, 130, 133-34, 141, 179, 191, 211, 268 n.57, 284 n.12).

However, the term derives from Richard Wollheim, Painting as an Art, London, 1987. 
Harrison explains that Leider's invitation was preceded by an offer from John Coplans to work at the Pasadena Art Museum or as associate editor at Artforum, with a view to a job at the Museum of Modern Art. Harrison politely declined this offer.

$4 \quad$ See also the special issue of nonsite.org Intention and Interpretation \#6, Summer 2012.

5 Boris Groys argues against this in his essay for the Attitudes catalogue. He writes, '... it makes no sense to speak, as it has become fashionable nowadays, about the power of the curator who allegedly subjugates the individual artistic works to his or her will. Here Harald Szeeman simply extends and further develops the relations between visual and textual documents... .' In 'Art Topology: the Reproduction of Aura', in When Attitudes Become Form: Bern 1969/Venice 2013. See Celant (2013, p. 453).

\section{References}

Alpers, Svetlana. 1976. Describe or Narrate? A Problem in Realistic Representation. New Literary History 8: 15-41. [CrossRef] Bailey, Robert. 2016. Art \& Language International: Conceptual art between Worlds. Durham: Duke University Press.

Baxandall, Michael. 1979. The Language of Art History. New Literary History 10: 457-58. [CrossRef]

Belilose, Marlène, and André Gazut. 1969. Quand les Attitudes Deviennent Forme. Geneva: Télévision Suisse Romande, April 6.

Brook, Donald. 1970. Art criticism: Authority and argument. Studio International 180: 925.

Buren, Daniel, Diane Waldman, Thomas Messer, and Hans Haacke. 1971. Gurgles Around the Guggenheim. Studio International 181: 246-50.

Butler, Rex. 2020. Rosalind Krauss: Between modernism and post-medium. Journal of Art Historiography 23: 3399. [CrossRef]

Celant, Germano, ed. 2013. Art Topology: The Reproduction of Aura. In When Attitudes Become Form: Bern 1969/Venice 2013. Milano: Fondazione Prada.

Costello, Diarmuid. 2012. Automat, Automatic, Automatism: Rosalind Krauss and Stanley Cavell on Photography and the Photographically Dependent Arts. Critical Inquiry 38: 819-54. [CrossRef]

Cronan, Todd. 2013. Against Affective Formalism: Matisse, Bergson, Modernism. Minneapolis: University of Minnesota Press.

Curley, John J. 2021. Banner of an Atomic Regiment: Morris Louis, Greenberg's Modernism, and Science c.1962. Art History 44: 130-62. [CrossRef]

Danto, Arthur. 1964. The Artworld. Journal of Philosophy 61: 571-84. [CrossRef]

Delacroix, Eugene. 1998. Journal Entry, Paris, 3 September 1857. In The Journal of Eugène Delacroix, Art in Theory: 1815-1900: An Anthology of Changing Ideas. Edited by Jason Gaiger and Paul Wood. Translated by Walter Pach. Reprinted in Harrison. Oxford and Maldon: Blackwell.

Deutsche, Rosalyn. 1986. Property Values: Hans Haacke, Real Estate, and the Museum. In Hans Haacke—Unfinished Business. Edited by Brian Wallis. New York: Museum of Modern Art.

Dickie, George. 1974. Art and the Aesthetic: An Institutional Analysis. Ithaca: Cornell University Press.

Forge, Andrew. 1971. Forces Against Object-based art. Studio International 181: 933.

Fried, Michael. 1967. The Achievement of Morris Louis. Artforum 5: 34-40.

Fried, Michael. 1996a. Morris Louis. In Art and Objecthood: Essays and Reviews. Chicago and London: University of Chicago Press, pp. 100-31.

Fried, Michael. 1996b. Three American Painters. In Art and Objecthood: Essays and Revierws. Chicago and London: University of Chicago Press.

Fried, Michael. 1996c. Shape as Form: Frank Stella's Irregular Polygons. In Art and Objecthood. Chicago and London: University of Chicago Press, pp. 77-99.

Fried, Michael. 1996d. Art and Objecthood. In Art and Objecthood: Essays and Reviews. Chicago and London: University of Chicago Press, pp. 148-72, Originally published in Artforum 5, June 1967, pp. 12-23.

Fried, Michael. 2008. Why Photography Matters as Art as Never Before. New Haven and London: Yale University Press.

Fried, Michael. 2010. The Moment of Caravaggio. Princeton: Princeton University Press.

Fried, Michael. 2016. No Problem. Representations 135: 140-49. [CrossRef]

Greenberg, Clement. 1970. Avant-Garde Attitudes. Studio International 179: 142-45.

Greenberg, Clement. 1993a. Louis and Noland. In Clement Greenberg: The Collected Essays and Criticism, Volume 4: Modernism with a Vengeance. Edited by John O'Brian. Chicago and London: University of Chicago Press, pp. 94-100, Originally published in Art International, May 1960.

Greenberg, Clement. 1993b. Introduction to an Exhibition of Morris Louis, Kenneth Noland, and Jules Olitski. In The Collected Essays and Criticism, Volume 4: Modernism with a Vengeance, 1957-1969. Edited by John O'Brian. Chicago and London: University of Chicago Press, pp. 149-53.

Greenberg, Clement. 1993c. Letter to the Editor. In Clement Greenberg: The Collected Essays and Criticism, Volume 4, Modernism with a Vengeance, 1957-1969. Edited by John O'Brian. Chicago and London: University of Chicago Press, pp. 209-12, Originally published in Art International 9: 1965.

Greenberg, Clement. 1999. Homemade Esthetics: Observations on Art and Taste. Edited by Janice van Horne. Oxford and New York: Oxford University Press.

Haacke, Hans. 1974. Statement. In Art in Society, Society into Art. London: VDG.

Harrison, Charles. 1968a. Jeremy Moon's Recent Painting. Studio International 175: 134-39.

Harrison, Charles. 1968b. Barry Flanagan's Sculptures. Studio International 175: 266-68. 
Harrison, Charles. 1968c. Where does the collision happen? [Interview with John Latham]. Studio International 175: $258-61$.

Harrison, Charles. 1968d. Dusseldorf Commentary: Prospect ‘68'. Studio International 176: 176-77.

Harrison, Charles. 1969a. London Commentary. Studio International 177: 910.

Harrison, Charles. 1969b. Against Precedents. Studio International 178: 90-93.

Harrison, Charles. 1969c. Some Recent Sculpture in Britain. Studio International 177: 907.

Harrison, Charles. 1969d. On Exhibitions and the World at Large [Seth Siegelaub Interview]. Studio International 178: 202-3, Republished in Gregory Battcock, ed. 1973. Idea Art: A Critical Anthology. New York: E. P. Dutton..

Harrison, Charles. 1970. A Very Abstract Context. Studio International 180: 927.

Harrison, Charles. 1971. Virgin Soils and Old Lands. Studio International 181: 201-5.

Harrison, Charles. 1972. Art \& Language Press. Studio International 183: 985.

Harrison, Charles. 1993. Abstraction. In Frascina, Francis; Charles Harrison. Primitivism, Cubism, Abstraction: The Early Twentieth Century. Edited by Gill Perry. New Haven and London: Yale University Press.

Harrison, Charles. 2001a. Essays and Art \& Language. Cambridge and London: MIT Press.

Harrison, Charles. 2001b. Conceptual Art and Painting: Further Essays on Art E Language. Cambridge and London: MIT Press.

Harrison, Charles. 2009a. Feeling the Earth Move. In Since 1950: Art and Its Criticism. New Haven and London: Yale University Press.

Harrison, Charles. 2009b. Sculpture's Recent Past. In Since 1950: Art and Its Criticism. New Haven and London: Yale University Press.

Harrison, Charles. 2009c. A Place of Work: Conceptual Art as Realist Practice. In Since 1950: Art and Its Criticism. New Haven and London: Yale University Press.

Harrison, Charles. 2009d. "Englishness" and "Modernism" Revisited. In Since 1950: Art and its Criticism. New Haven and London: Yale University Press.

Harrison, Charles. 2009e. Keeping Up. In Since 1950: Art and its Criticism. New Haven and London: Yale University Press.

Hughes, Robert. 1990. Nothing If Not Critical: Selected Essays and Reviews. London: Harvill, Originally published as 'Morris Louis', Time, 1986.

Jones, Caroline A. 2005. Eyesight Alone: Clement Greenberg and the Bureaucratisation of the Senses. Chicago and London: Chicago University Press.

Kosuth, Joseph. 1991. Art After Philosophy. In Art After Philosophy and After: Collected Writings, 1966-1990. Cambridge and London: MIT Press, pp. 13-31. First published 1969.

Krauss, Rosalind E. 2000. A Voyage on the North Sea: Art in the Age of the Post-Medium Condition. London: Thames \& Hudson.

Krauss, Rosalind E. 2010. A View of Modernism. In Perpetual Inventory. Cambridge and London: MIT Press.

Krauss, Rosalind E. 2015. Willem de Kooning Nonstop: Cherchez la Femme. Chicago and London: MIT Press.

Melvin, Jo. 2011. Charles Harrison: Looking Back. London: Ridinghouse.

Melvin, Jo. 2013. Studio International Magazine: Tales from Peter Townsend's Editorial Papers 1965-75. Ph.D. thesis, University College, London, UK.

Melvin, Jo. 2016. The British Avant Garde: A Joint Venture Between the New York Cultural Center and Studio International Magazine. British Art Studies. [CrossRef]

Moon, Jeremy. 1971. Enemies of Painting. Studio International 182: 939.

Moore, Jane. 2008. 'What Sir Luke Fildes' The Doctor can tell us about the practice of medicine today. The British Journal of Medical Practice 58: 210-13.

Morris, Robert. 1968. Anti Form. Artforum 6: 8.

Reise, Barbara. 1971. A tail of two exhibitions. Studio International 182: 30-38.

Robbins, Daniel. 1962. Morris Louis: Triumph of Color. Art News 62: 28-29, 57-58.

Rose, Sam. 2017. Close Looking and Conviction. Art History 40: 156-77. [CrossRef]

Schjeldahl, Peter. 1991. A Visit to the Salon of Autumn 1986. In The Hydrogen Jukebox: Selected Writings of Peter Schjeldahl 1978-1990. Edited by Malin Wilson. Berkeley: University of California Press, Originally published in Art in America 74, December 1986: 15-21.

Schreyach, Michael. 2017. Pollock's Modernism. New Haven and London: Yale University Press.

Singerman, Howard. 2003. Noncompositional Effects, or the Process of Painting in 1970. Oxford Art Journal 26: 125-50. [CrossRef]

Upright, Diane. 1985. Morris Louis: The Complete Paintings, a Catalogue Raisonné. New York: Harry N. Abrams.

Welchman, John. 1992. Bordering On. Paper presented at Boundary Rider: 9th Biennale of Sydney, Sydney, Australia, 15 December 1992-14 March 1993; Edited by Anthony Bond. pp. 34-42.

Welchman, John. 1996. In and Around the "Second Frame". In The Rhetoric of the Frame. Edited by Paul Duro. Cambridge: Cambridge University Press.

Wollheim, Richard. 1987. Painting as an Art. London: Thames \& Hudson. 